\title{
The Larval Stages of Nassarius reticulatus and Nassarius incrassatus.
}

By

\author{
Marie V. Lebour, D.Sc.
}

Naturalist at the Plymouth Laboratory.

With 3 Figures in the Text and Plates 1-V.

The two species of Nassarius (usually known as Nassa), N. reticulatus and $N$. incrassatus, are both common at Plymouth. N. reticulatus, the larger species, occurs from low water usually to a depth of a few fathoms, more rarely from the waters outside the Breakwater, $N$. incrassatus occurring between tide-marks and extending into deeper water, even to 46 fathoms.

The egg capsules of both are well known. It is necessary, however, to modify a general statement present in most popular mollusc and natural history works (for instance, Cooke, 1895, p. 125), quoted by Flatteley and Walton (1922, p. 272), that "Nassa reticulata lays egg capsules in shape like flattened pouches with a short stalk. . . . Nassa incrassata deposits solitary capsules which are shaped like rounded oil-flasks."
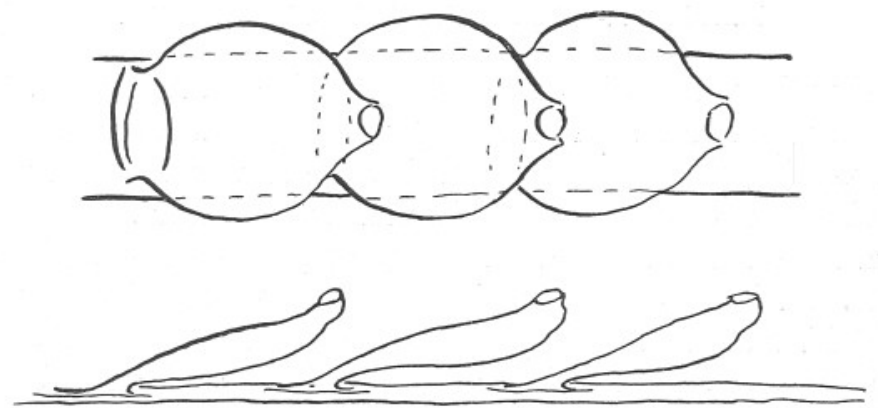

Texт-Fig. 1.-Egg capsules of Nassarius reticulatus on Zostera.

In reality both lay egg capsules like flattened pouches, the general shape being much alike, but those of Nassarius reticulatus are nearly three times the height of those of $N$. incrassatus; the pouch is flattened in one direction and almost round in the other, that of $N$. reticulatus being rather flatter than $N$. incrassatus. The adhesive base is broad in $N$. reticulatus and hardly to be called a stalk, whilst in $N$. incrassatus it 
is narrower and more stalk-like. The mouth of the pouch is more pronounced in $N$. incrassatus. The capsules have a slanting position, the flat surface uppermost (Plate I and Text-figures 1 and 2). Both species may lay the capsules on Zostera, but this is usual in N. reticulatus and there are generally many in a row. There may, however, be only one, two or three, and occasionally they are laid in clusters of rows on hydroids or on Bryozoa. N. incrassatus usually lays the capsules irregularly in clusters on some rough surface, especially on hydroids or on Bryozoa, but occasionally they are to be found singly and sometimes on Zostera. When on Zostera they are more usually clustering in crevices near the roots, but as many as three in a row have been found on Zostera leaves. In support of this statement we find that Fischer (1892), who was the first to describe the capsules of what is almost certainly $N$. incrassatus,

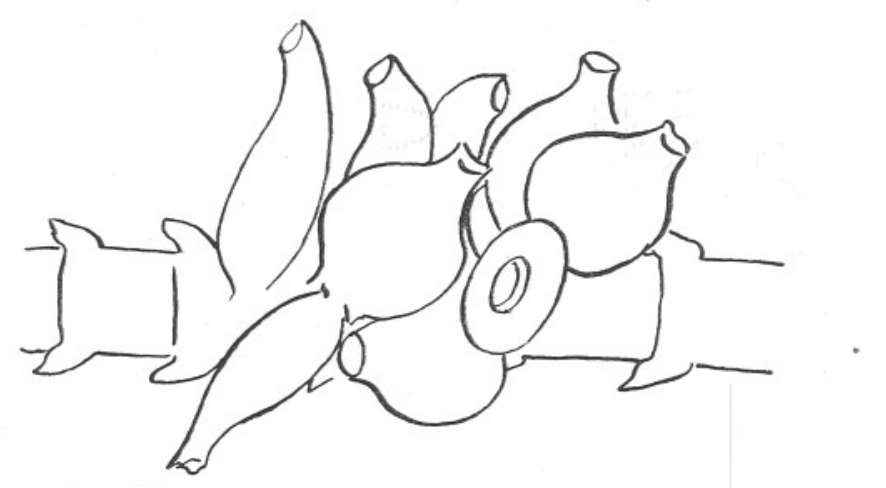

Text-Fig. 2.-Egg capsules of Nassarius incrassatus.

states that they occurred two or three at a time on Zostera. His figure shows a broader base than in the Plymouth specimen, but the size (not over $2 \mathrm{~mm}$.) and the fact that $N$. incrassatus was common where he collected the eggs make the identification almost certain.

From 50 to 100 eggs, sometimes less, sometimes more, are laid in the capsules. $N$. incrassatus usually lays from 50 to 80 , rarely more, in each capsule, $N$. reticulatus usually upwards of 100 . Usually all the eggs develop and there are no "nurse eggs," which are devoured by their neighbours, as is the case in certain other gastropods, notably Buccinum undatum, Nucella (=Purpura) lapillus, Natica catena and Rissoa membranacea. There is thus an enormous number of young hatched out and swimming about in the sea as veligers, both species hatching with wellformed shell and bilobed velum. Up to this stage the larvæ, especially those of $N$. reticulatus, are well known, and it is apparently usually supposed that they have a short free-swimming life and soon settle down to be like their parents. 
Pelseneer (1911) gives an account of the eggs and larvæ of $N$. reticulatus up to the time of hatching, but he could not rear them longer than two or three days. He describes and figures the developing embryos and newly-hatched larvæ and his descriptions agree very well with the Plymouth specimens. He also figures the egg capsules and larval shell in Lankester's Treatise of Zoology; Mollusca, 1906, pp. 130, 135, and the egg capsules again in his paper of 1926, in which he describes the egglaying. Recently Ankel (1929) has investigated the laying of the egg capsules in $N$. reticulatus and given photographic illustrations of these. The following notes will show that both species have a long free-swimming period lasting for two months or more (at any rate under Laboratory conditions) and grow to a large size before losing the velum. For this
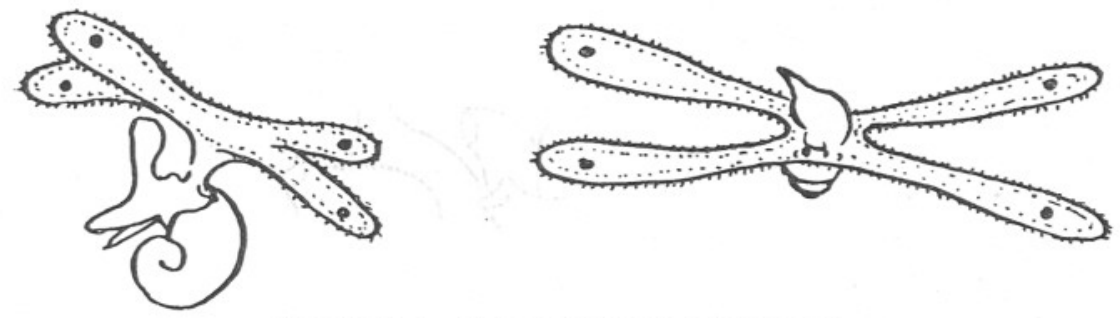

Text-Fig. 3.-Larvæ of Nassarius incrassatus.

reason they are a very important constituent of the plankton both inshore and outside, and they must form a large part of the food of the larger plankton-eating animals.

In late spring and summer a larval gastropod is always conspicuous in the Plymouth plankton, occurring in the water outside the Breakwater more commonly than any other mollusc (except the pteropod Limacina retroversa which may be present at the same time in very large numbers) and it is also common in the inshore plankton. The later stages of this larva, and it is these which commonly occur outside, show an enormously developed four-lobed velum. By keeping these in a plunger-jar it was found that they grew into Nassarius incrassatus (Plate IV, Fig. 8; Textfigure 3). Adults were then collected, eggs obtained and the larvæ reared to a certain stage. Eggs of $N$. reticulatus were obtained from the Zostera, hatched and reared until they began to crawl. This took two months. There is every indication that the free-swimming period is even longer in N. incrassatus.

It is now possible to give an account of the life-history of both these species from experiments and observations in the Laboratory and from freshly collected material from dredge, trawl and tow-net. 


\section{Methods.}

Eggs of both species were collected whenever possible and plankton hauls investigated continually. The two species of Nassarius were placed in aquaria, aerated glass vessels, plunger-jars and Laboratory tanks.

Although later on some were found to be depositing eggs in the tanks, in none of these cases did $N$. reticulatus lay eggs in captivity, but $N$. incrassatus laid them easily in plunger-jars on the glass, on Zostera roots and on pieces of Bryozoa and hydroids. The eggs of $N$. reticulatus laid on Zostera were collected, the capsules removed from the Zostera and placed in a plunger-jar. These hatched out early and were kept in the same vessel for over two months without change of water. A pure culture of Nitzschia was added to the water, and this diatom, together with others which appeared naturally in the water, served as food for the larvæ. Unfortunately towards the end of the two months the flagellate Phæocystis appeared in the jar, and although this was eaten by the larvæ to a certain extent it soon became too dense and killed everything off. Some of the larvæ had, however, reached the crawling stage. From the first it could be seen that diatoms and other minute objects were in the stomachs of the larvæ, the contents always in a violent state of agitation owing to the ciliated lining of the stomach. Later on larger diatoms could be detected and the larvæ ate Skeletonema costatum and Thalassiosira gravida besides Nitzschia. These were the main forms growing in the jar and it was interesting to note that chains of Skeletonema and Thalassiosira were to be seen in the stomach and not only separate cells. That Skeletonema, which is one of the commonest diatoms, one of the easiest to culture, and one which is always penetrating into other cultures, should be a common food for a larval molluse is an interesting and important fact. It is evident that diatoms form the chief food of these larvæ throughout their free-swimming life.

The larvæ of $N$. incrassatus were also fed in the same way, but they did not live so long and intermediate stages were collected from the plankton. In all cases when examined for food the natural food of both species in the free-swimming stage was essentially diatom material. The late larvæ of $N$. incrassatus were put into a plunger-jar provided with diatoms. As they grew and began to crawl, small mollusc larvæ from the plankton, chiefly bivalves, were introduced and evidently served well as food for those which had lost the velum. A stage exists in both species in which the velum is still retained although the foot is well developed. The mollusc can thus crawl or swim at will. It is apparently still a plankton feeder for some time and continues to eat diatoms, but when the velum begins to disappear, and afterwards, it is apparently carnivorous. Small bivalves, especially Anomia, settled down on the glass sides of the plunger- 
jar and these were eaten by the young Nassarius, some of which were actually seen to attack them. In this way $N$. incrassatus was reared to the adult stage.

The water for rearing was taken from outside the Breakwater where there were many diatoms, and these diatoms naturally present were eaten quite as much as the Nitzschia which was introduced. In all cases the food was chiefly Skeletonema, Thalassiosira and Nitzschia, always mixed with small indistinguishable particles, probably both organic and inorganic.

\section{Characters of the Two Species.}

The egg capsules are a light horn colour, transparent, and the eggs visible through the wall of the capsule (Plate I). About a month is the usual time taken from the deposition of the eggs to the time of hatching. This is the time given by Pelseneer, and it is much the same in the Laboratory, the eggs of $N$. reticulatus from very early capsules hatching in from three to four weeks, those of $N$. incrassatus newly laid in the Laboratory hatching in twenty-three to thirty days. The ages of the larvæ when known and the sizes given are all under the ordinary Laboratory conditions of temperature. A comparison with those from the plankton shows much the same state of development at the same size. Some time before hatching the larvæ are moving about as veligers inside the capsule, with the shell already formed, much yolk being inside each larva, and when all the yolk is absorbed the larva hatches, escaping from the top of the capsule where a thin covering is broken through.

The newly hatched larva (Plate II, Figs. 1, 2; Plate III, Fig. 1; Plate IV, Figs. 1, 2) has a smooth unsculptured shell, very transparent, consisting of one whorl. The outer lip is slightly drawn out at the centre, curving inwards so that two hollows are formed to support the velum. This projection grows into a conspicuous tooth bent inwards and the hollows deepen as the velum grows (Plate III, Fig. 2 ; Plate V, Figs. 3, 7). The animal has a bilobed velum, rather longer across than the greatest breadth of the shell, with the usual ciliated margin and ciliated ridge below forming a groove to the mouth. The general method of feeding in a veliger is for the food to be collected whilst the animal is swimming. This is done by means of the velum. Round the margin of the velum is a thick rim edged with large cilia. On the underside and somewhat internal to the margin is another smaller ridge edged with smaller cilia. These two ridges form a groove in which the food is collected and brought to the mouth (Plate V, Fig. 6). The mouth is also ciliated and the united workings of the cilia on the velum and round and inside the mouth bring a constant supply of small food to the animal. Mucus appears to be secreted in the groove and if the particles are not suitable the animal 
swims away from them, leaving them behind entangled in a stream of mucus. However large and elaborate the velum may be, the process of feeding seems to be the same. As the foot grows and crawling begins the radula has been forming and soon a different method of feeding may come into use, until finally the velar method is abandoned and the ordinary adult carnivorous method substituted.

At first the paired eyes are at the base of very short tentacles. Sometimes, as Pelseneer (1911) points out, but not always, only one tentacle is developed, the other not appearing till later. There are paired otoliths at the base of the foot. The ventral mouth just below the velum, œsophagus, stomach, intestine and anus are all visible, the liver lobes occupying the apex of the shell, the kidney is present and the heart beating. The stomach is ciliated and food material always moving about inside. The rectum and anus are on the right side (Plate III, Fig. 5 ; Plate V, Fig. 5). The veliger moves quickly by means of the long cilia on the velum which is fully expanded. Later the flapping of the lobes helps in the movement.

The larva grows quickly, but has a long free-swimming period. After a few weeks the velum becomes four-lobed and the colour, if not already present, is accentuated in certain regions, the shell begins to be spiral and the shell siphon or canal is formed (Plate II, Figs. 2-11; Plate III, Figs. 3-5 ; Plate IV, Figs. 3-8; Plate V, Figs. 2-5). The velum may remain only slightly four-lobed (N. reticulatus, Plate II, Figs. 8-9), or the lobes may grow out to an enormous length ( $N$. incrassatus, Plate IV, Fig. 8; Text-Fig. 3). The foot, situated behind the velum, is ciliated on the whole of its surface; at first a very small projection narrowing behind, but always provided with an operculum, it soon lengthens and a few large cilia project at its hind end. In later stages the front of the foot grows forward into a flexible process, still ciliated (Plate II, Figs. 7-9 ; Plate IV, Figs. 7-8). The tentacles grow longer and are also ciliated, the tips having a few large cilia and the whole surface covered by minute cilia. Pigment appears on the base of the foot and round the mouth. In $N$. reticulatus there is from the first a border of brown pigment round the velum, in $N$. incrassatus the velum is at first colourless, then brown pigment appears and gradually concentrate with a large spot at each corner of the four lobes. After some weeks the shell has from three to four whorls and the canal (the shell siphon) is fully formed, containing the siphon proper. When the animal can crawl there are from three to four whorls, the larval shell mouth has no longer the projecting tooth but the margin is simple with a slightly crenulated edge (Plate II, Figs. 12-14 ; Plate V, Figs. 8-9). The head end projects slightly and the front of the foot is provided with two horns. The foot itself is elongated and the siphon very long. Ribs may begin to appear on the shell. The animal is 
now outwardly like the adult except for the sculpture on the shell, and probably attains maturity in a year or less.

\section{Nassarius Reticulatus (L.).}

\section{(Plates I, Figs. 1-2 ; II and III : Text-Fig. 1.)}

The eggs are laid in spring and summer, usually from March to August, more rarely in autumn and winter, in the inshore waters; occasionally further out in deeper water. Records of eggs show that they may be laid every month, except October and November (Plymouth Marine Fauna, new edition, 1931). Probably a few eggs could be found in any month of the year. Breeding is usually finished by the end of September, but three capsules were found on Zostera from Cawsand Bay, 28.1.31, perhaps the earliest of the season. The best localities for the egg capsules are the Zostera beds in Cawsand Bay and off Drake's Island. One large mass from outside waters in June, 1931, consisted of many clusters of rows laid in a tangle of Antennularia and Sertularella.

The capsule measures about 4.8 to $5 \mathrm{~mm}$. in height and about $4 \mathrm{~mm}$. across the widest part. The newly laid egg measures about $0.16 \mathrm{~mm}$. across, but grows rapidly and is much bigger as the embryo develops. The newly hatched larva measures about $0 \cdot 28 \mathrm{~mm}$. to $0.30 \mathrm{~mm}$. across at its widest part, which is across the body whorl to the outer lip. The velum measures about 0.29 to $0.32 \mathrm{~mm}$. across and has a continuous reddish brown border just inside the margin. The outer lip of the shell is conspicuous in its projecting centre curving inwards, forming almost immediately the characteristic tooth (Plate II, Figs. 1, 2 ; Plate III, Figs. 1, 2, 3). The shell and velum both grow quickly, the shell at five days old measuring about $0.32 \mathrm{~mm}$. across, the velum $0.45 \mathrm{~mm}$. across. The tentacles are well developed and there is a small amount of brown pigment on the ventral surface of the foot. At about three weeks old the shell measures about $0.4 \mathrm{~mm}$. to $0.5 \mathrm{~mm}$. across, the velum being about 0.48 to $0.55 \mathrm{~mm}$. across. The outer lip is now drawn out posteriorly, forming the canal or shell siphon, and the spire begins to project. The foot is perceptibly longer and the dark pigment round the mouth is conspicuous. The larva now begins to show an alteration in the velum, and when about twenty-five days old there is an indentation at each side, the the first indication of the four lobes, and the width across grows larger. The animal now looks like a butterfly with outspread wings. The velum in $N$. reticulatus, however, is never so large, nor the lobes so long as in $N$. incrassatus. When about five weeks old the shell has from two to three whorls and measures about $0.56 \mathrm{~mm}$. across, the velum being about $1.3 \mathrm{~mm}$. across. The reddish-brown border to the velum is very conspicuous throughout the larval life. At about six weeks there are three 
whorls to the shell and the velum, sometimes larger anteriorly, may measure about $2 \mathrm{~mm}$. across. The foot has now grown out into a squarish lobe in front and there is much brown pigment. The tentacles are long. The size may vary and a rather later stage may be smaller than a younger one, as in Figs. 8 and 9 of Plate II. After this the anterior lobe of the foot expands into two horns and the animal is able to crawl. It may now measure $0.72 \mathrm{~mm}$. to $0.8 \mathrm{~mm}$. across from the outer lip margin to the body whorl ; the outer tooth-like process has disappeared and the edge slightly crenulated (Plate II, Figs. 10-14). There is a long siphon, the foot projects some way beyond the spire when crawling and the tentacles are like the adult. It now crawls or swims at will, but the velum soon dwindles and then probably disappears altogether in a few weeks. At the first crawling stage $N$. reticulatus (about $0.8 \mathrm{~mm}$. long) is decidedly smaller than $N$. incrassatus (about 1 to $1.2 \mathrm{~mm}$.), although the latter species is so much smaller when adult.

All the stages are usually to be found in the inshore plankton in spring and summer and are seldom seen outside. They are exceedingly common inside the Sound.

\section{Nassarius incrassatus (Ström.).}

(Plate I, Figs. 3-4 ; Plates IV and V: Text-Figs. 2-3.)

The Plymouth Marine Fauna, new edition, 1931, records a mass of the egg capsules taken when the animal was actually depositing them on tufts of Antennularia, 25.1.09. Other records show that eggs were found every month except July. It is probable that a few may be found any month of the year, but the larvæ are much the commonest in spring and summer and are rarely seen in the autumn except when very young. Several adults were collected and placed in a plunger-jar in October and November, 1930, and on the 5th and 6th of November some capsules with eggs nearly ready to hatch were found in the jar attached to a mass of Cellaria on which were some eggs of Parasepia elegans. There were also capsules on the Parasepia eggs. Later in November and through December, January and February capsules were found on the sides of the glass jar, again on Cellaria and on pieces of Sertularella placed there for the purpose, and, later, from February to April, they were laid in clusters in crevices at the roots of Zostera floating in the jar. Very rarely they were laid on the Zostera leaves. Egg capsules were also found through May and June. All through June, July and August the late larvæ were abundant in the inside and outside plankton, and in winter, spring, summer, and more rarely in autumn the early larvæ could be found in the inshore waters. The younger forms are seldom seen far out. It is probable that most of the large larvæ come from inshore where the adults are so plentiful and they are so strong and large that they survive 
when the smaller larvæ would perish. The length of larval life and their propensity for being carried out to sea would account for the very wide distribution and large numbers of this common species.

The egg capsules measure about $1.5 \mathrm{~mm}$. to $2 \mathrm{~mm}$. in height, the greatest breadth being rather less than the height. The eggs when newly laid measure $0.16 \mathrm{~mm}$. across, which is the same size as those of $N$. reticulatus, although the newly hatched larvæ are smaller than in that species. The newly hatched larvæ are at first like $N$. reticulatus, but without any pigment on the velum. The shell measures $0.18 \mathrm{~mm}$. to $0 \cdot 2 \mathrm{~mm}$. across and the velum about $0 \cdot 2 \mathrm{~mm}$. to $0 \cdot 24 \mathrm{~mm}$. across. At first growth and development take place in a similar way to $N$. reticulatus, but the pigment on the velum only appears after a few days.

Although the early larvæ are at first smaller than $N$. reticulatus at the same stage, yet in the later stages they are larger and the velum grows out into four very long lobes.

It was unfortunately not possible to rear these larvæ for longer than three weeks, but intermediate stages were collected from the plankton and the later stages were reared in a plunger-jar to the adult. Three of these which were placed in the jar in August, 1930, when they were freeswimming veligers, are now fully grown (July, 1931).

In about fourteen days the larvæ reared from the egg measured about $0.32 \mathrm{~mm}$. across. Pigment may or may not be present on the velum at this stage, but at about three weeks old there are irregular masses of brown pigment which soon concentrate to form a large spot at each corner. The velum also begins to be four-lobed and shaped much like that of $N$. reticulatus at a slightly older stage, and when the shell is about $0.5 \mathrm{~mm}$. across the lobes are much more divided than in the latest stage of $N$. reticulatus, at $0.8 \mathrm{~mm}$. the lobes of the velum are about at their longest and each lobe is quite twice as long as the shell (Plate IV, Fig. 8). When the shell is about $1.2 \mathrm{~mm}$. the animal can either crawl or swim and at about $1.5 \mathrm{~mm}$. the velum is lost. It is probable that the larva of $N$. incrassatus remains in the free-swimming stage even longer than $N$. reticulatus, which takes two months under Laboratory conditions to reach the crawling stage.

These late veligers collected from the plankton were watched in the plunger jars. Here they could be seen swimming. Sometimes they remained still, the velum outspread upwards, the shell hanging down, or else the velar lobes were flapping and the movement was like that of the wings of a pteropod (Text-Fig. 3). When the lobes are spread out the animal is moving very slowly, and it is then that the food is directed into the mouth.

We have now ascertained the life-histories of both the Plymouth 
species of Nassarius which can be recognised in all stages in the plankton and distinguished from one another and from other larval gastropods found with them. The unsculptured shell and the prominent tooth on the outer lip, which is apparent almost directly, distinguish the Nassarius larvæ from others of the same size. Later on the half-grown larvæ of $N$. incrassatus have a four-lobed velum with four spots much like a commonly occurring larva belonging to Natica (probably $N$. catena). The Natica, however, has no shell siphon and is always to be distinguished.

The two Nassarius larvæ are to be recognised in the following ways :-

$N$. reticulatus.

All its larval life has a band of brownish-red pigment round the inside margin of the velum.

Velum at first bilobed, then fourlobed, but lobes never long.

Newly hatched larva $0 \cdot 28 \mathrm{~mm}$. to $3 \mathrm{~mm}$. across shell.

First crawling stage about 0.75 to $0.8 \mathrm{~mm}$.

Two months under Laboratory conditions from hatching to first crawling stage.
$N$. incrassatus.

At first colourless, then faint scattered brown pigment forming an irregular border, later on concentrated in four large spots, one at each corner of the velum.

Velum at first bilobed, gradually becoming four-lobed, the lobes in late stages very long.

Newly hatched larva $0.18 \mathrm{~mm}$. to $0 \cdot 2 \mathrm{~mm}$. across shell.

First crawling stage about $1 \cdot 2$ $\mathrm{mm}$. Probably more than two months from hatching to first crawling stage.

\section{LITERATURE.}

Ankel, W. E. 1929. Ueber die Bildung der Eikapsel bei Nassa-Arten. Verhandlungen der Deutschen Zoologischen Gesellschaft E. V. Zool. Anz. Supp. Bd. IV, pp. 219-230.

Cooke, G. H. 1895. Mollusca. Cambridge Natural History, pp. 1-295.

Fischer, H. 1892. Recherches sur la Morphologie du Foie des Gastéropodes. Bull. Sci. France et Belgique, XXIV (4), Vol. III, pp. 260 346.

Flatteley, F. W., and Walton, C. L. 1922. The Biology of the Seashore, pp. 1-336.

Marine Biological Association. Plymouth Marine Fauna, new edition, 1931. 
Pelseneer, P. 1906. Mollusca. Lankester's Treatise on Zoology, pp. 1-355.

Pelseneer, P. 1911. Recherches sur l'Embryologie des Gasteropodes. Mem. de l'Acad. Roy. de Belgique, 2me Sér. T. III, pp. 1-167.

Pelseneer, P. 1926. Notes d'embryologie malacologique. Bull. Biol. de la France et de la Belgique, T. LX, F. 1, pp. 88-112. 


\section{KEY TO FIGURES.}

Scale B is six times the scale of A.

PLATE I.-Egg capsules of Nassarius reticulatus and $N$. incrassatus. Scale A.

FIG. 1.-N. reticulatus, $0.48 \mathrm{~mm}$. high.

FIG. 2.-The same, side view.

FIG. 3.-N. incrassatus, $2 \mathrm{~mm}$. high.

FIg. 4.-The same, side view. 
PLATE I.

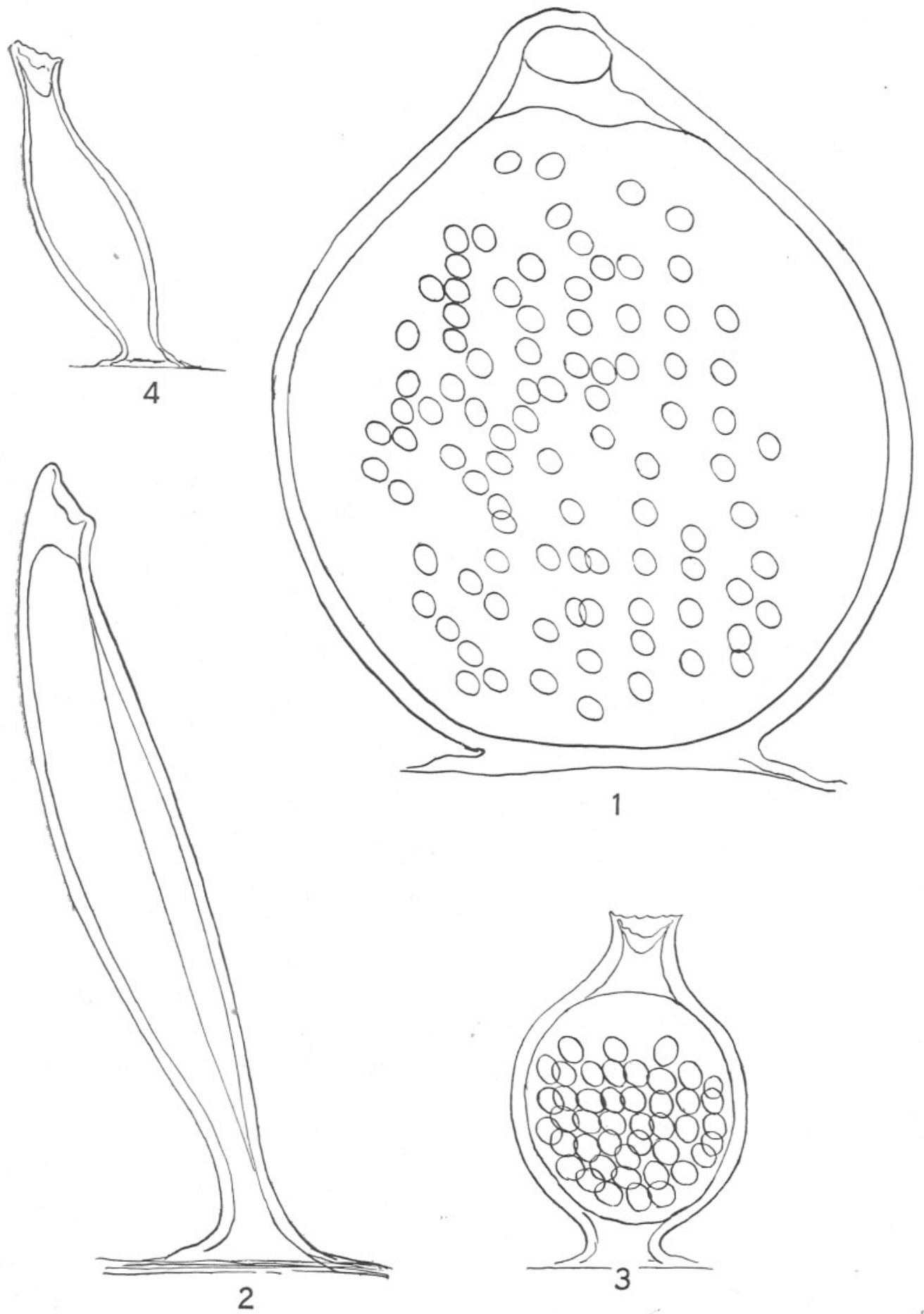

NEW SERIES,-VOL. XVII. NO. 3. OOTOBER, 1931. 
PLATE II.-Larvæ of Nassarius reticulatus reared from egg. Scale A.

Figs. 1-2.-Newly hatched, shell $0 \cdot 25 \mathrm{~mm}$. across body whorl.

FIG. 3.-7 days old, $0 \cdot 32 \mathrm{~mm}$.

Frg. 4.-19 days old, $0.45 \mathrm{~mm}$.

Fig. 5.-25 days old, $0.56 \mathrm{~mm}$.

FIG. 6.-32 days old, $0.64 \mathrm{~mm}$.

Fig. 7.-35 days old, $0.7 \mathrm{~mm}$.

Fig. 8. -40 days old, $0.75 \mathrm{~mm}$.

Fig. 9. -48 days old, $0.75 \mathrm{~mm}$.

Figs. 10, 11.-The same swimming in different positions.

Figs. 12-14. Crawling stages, 50 days to two months old. 
PLATE II.

(3)
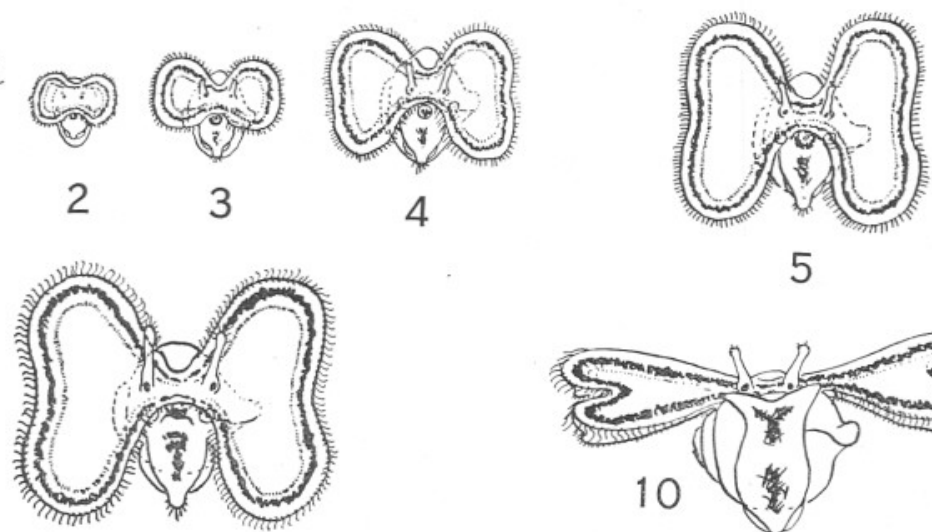

5

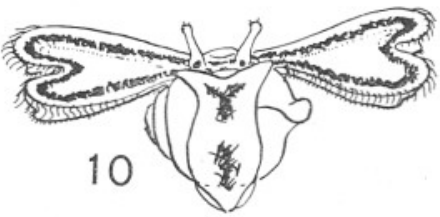

6
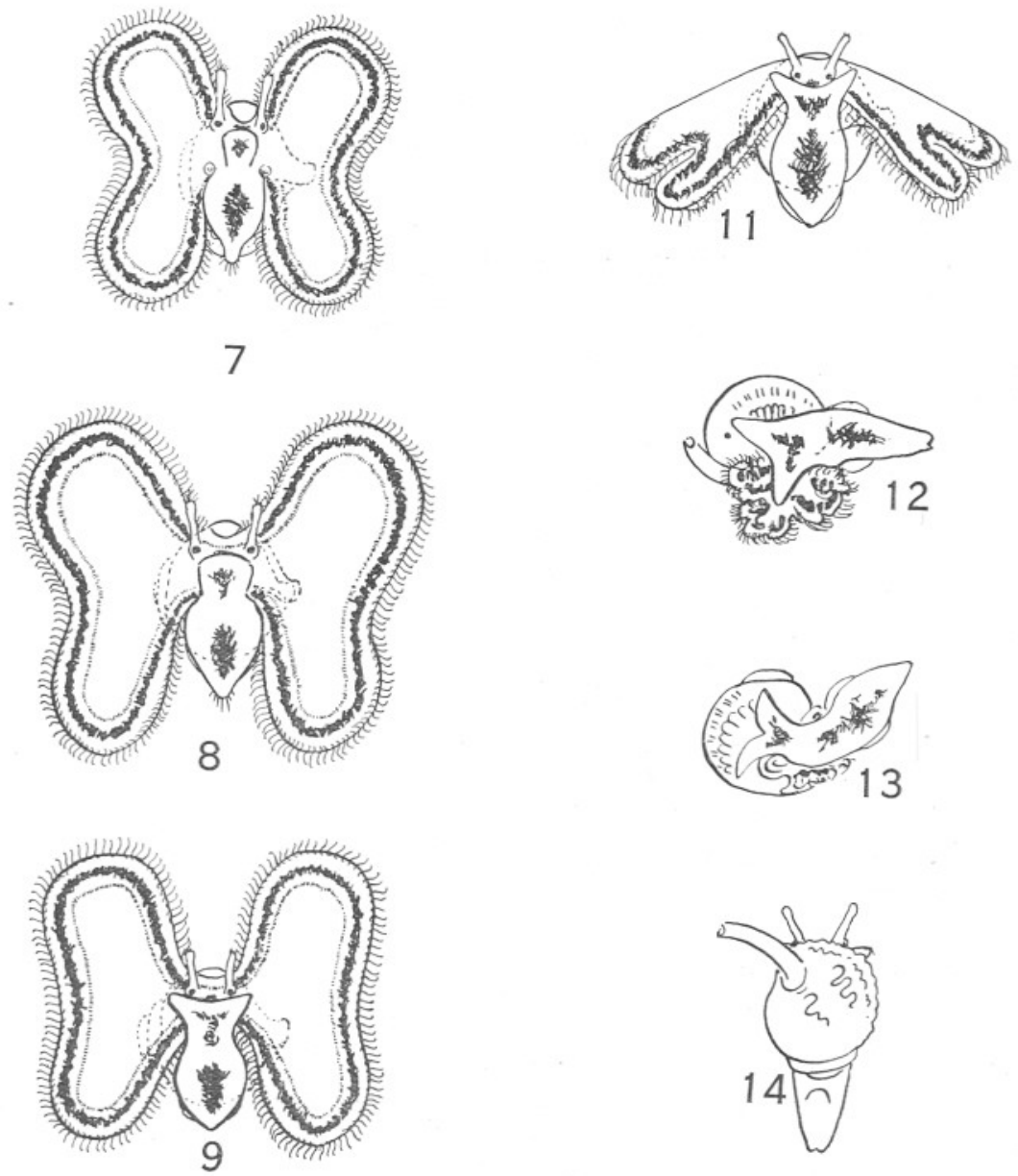
PLATE III.-Larvæ of $N$. reticulatus reared from egg. Scale B.

Fig. 1.-Shell of newly hatched larvæ.

FIg. 2.-Shell of larva 5 days old.

Fig. 3.-Larva 3 days old.

Figs. 4-5.-Larva 19 days old. 
PLATE III.
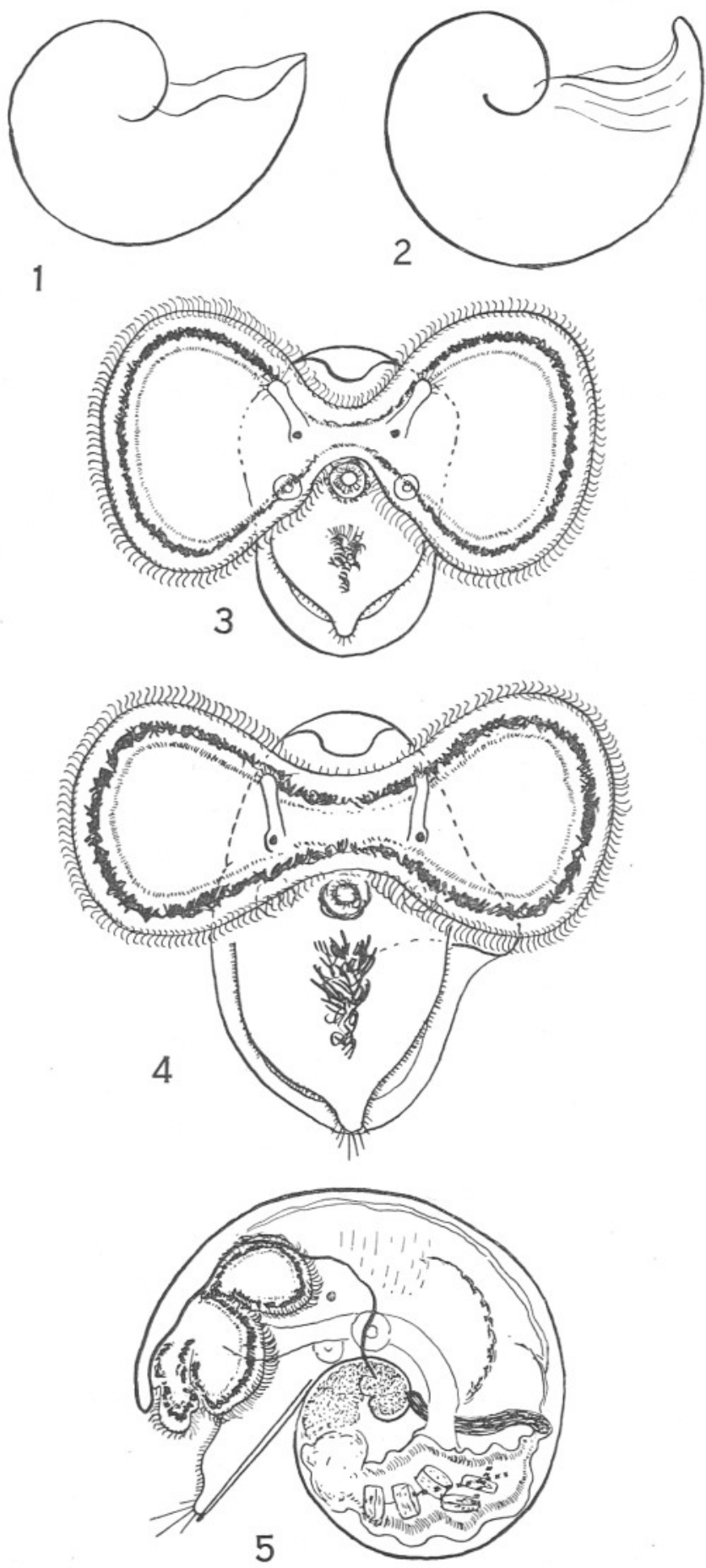
PLATE IV.-Larvæ of Nassarius incrassalus. Scale A. (1-3 from egg, 4-1l from plankton.)

Frgs. 1-2.-Newly hatched larva, $0 \cdot 18 \mathrm{~mm}$. across body whorl.

Fig. 3.-14 days old, $0 \cdot 32 \mathrm{~mm}$.

Figs. 4-7.-Larvæ from plankton, the ages being probably from 3 weeks to 3 months or more.

Fig. 4. $-0.35 \mathrm{~mm}$. across.

FIG. 5.-0.44 mm.

Figs. 6-7.- $0.55 \mathrm{~mm}$.

Fig. $8 .-0.8 \mathrm{~mm}$.

Fig. 9.-Shell of Fig. 7.

FIGs. 10-11.-Shells of crawling stage. 
PLATE IV.

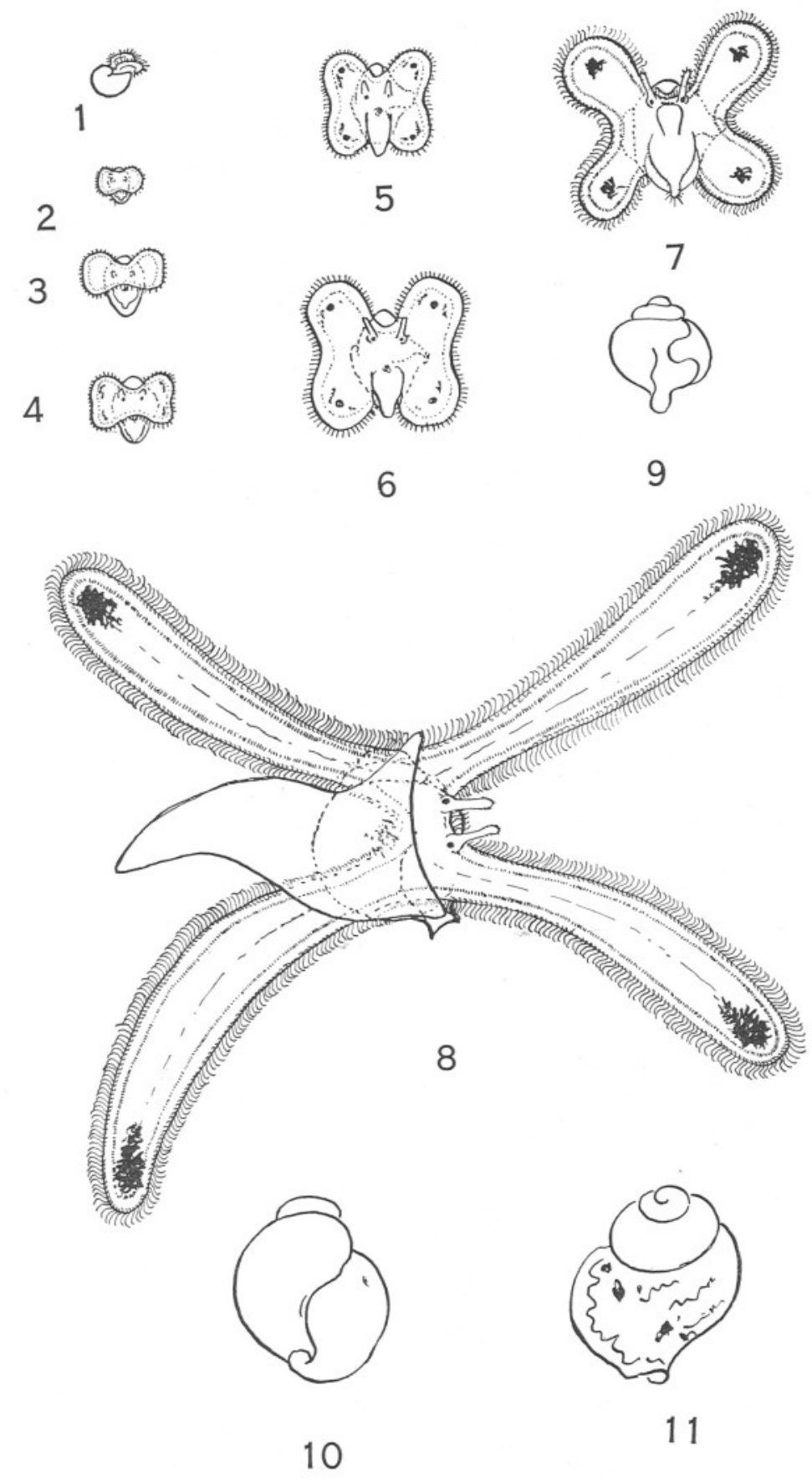


PLATE V.-Larvæ of $N$. incrassatus (1-6 Scale B, 8 and 9 drawn on a smaller scale).

FIG. 1.-Larva still in egg capsule nearly ready to hatch.

Fig. 2.-3 days old.

Figs. 3-5.-2 weeks old.

Figs. 6-7.-Ca. 3 weeks old.

Fig. 8.-Larva crawling; but still retaining velum shell $1.2 \mathrm{~mm}$. long.

Fig. 9.-Larva losing velum, shell $1.5 \mathrm{~mm}$. long. 


\section{PLATE V.}

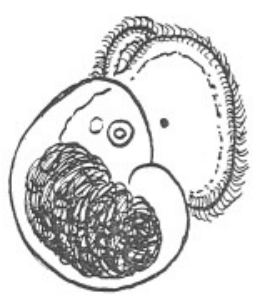

1

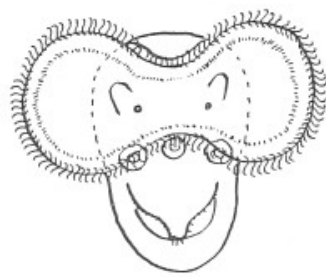

2

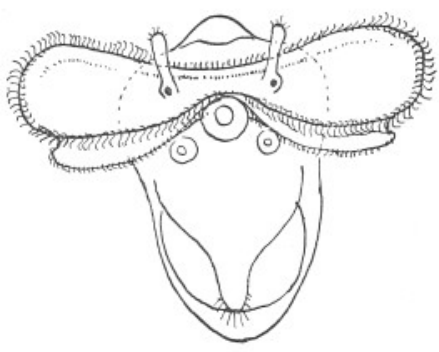

6

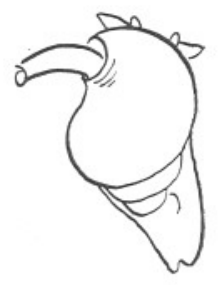

8

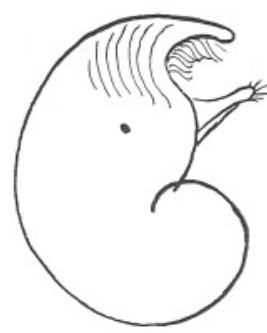

3
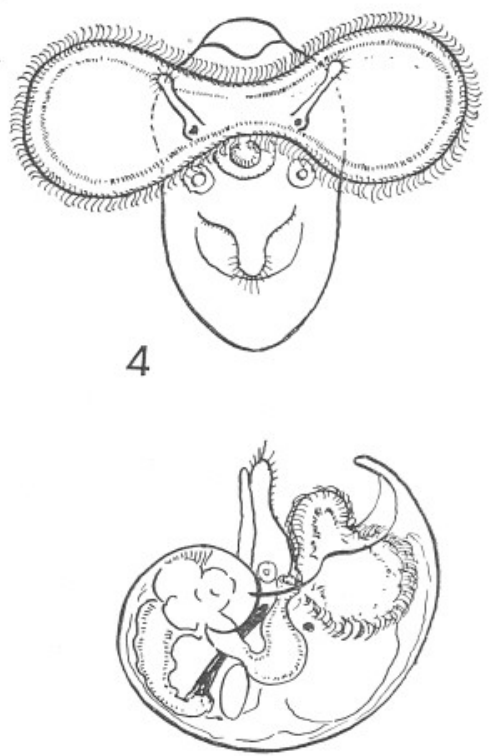

5

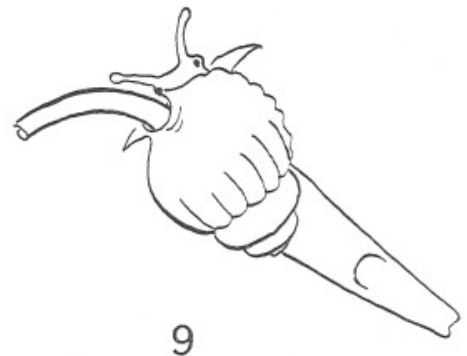

9

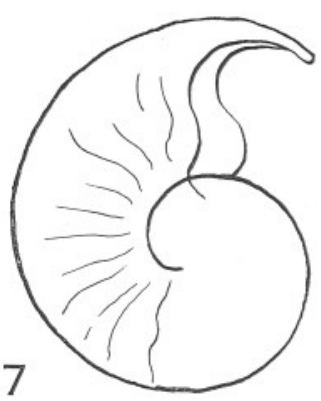

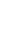


